\title{
Kategeet en spiritualiteit
}

\author{
C J H Venter
}

Vakgroep Praktiese Teologie, Skool vir Kerkwetenskappe

Noordwes-Universiteit (Potchefstroomkampus)

\begin{abstract}
Catechist and spirituality

This article argues that catechetical instruction pertains to more issues than only transferring knowledge. The catechist's spirituality can also contribute towards effective and convincing cathechetical instruction. The issue of the catechist's spirituality is scrutinized, as well as the foundation and source of his/her spirituality. For the purpose of this article spirituality is defined as the way in which human beings, as made new in Christ, experience the gospel and apply it to the practice of life, also in teaching the Bible to children in catechetical work. On basis-theoretical level, attention is given to the occurence of the concept "spirituality" in the New Testament and the characteristics required of a catechist in his/her relationship with God. Special attention is given to the issue of modelling, and identification with the catechist. On a meta-theoretical level the focus is directed to the catechist's personality including emotional intelligence and the way in which it functions within the framework of his/her spirituality. In conclusion certain practice-theoretical perspectives on catechist and spirituality are stated.
\end{abstract}

\section{INLEIDING}

\section{1 'n Nadere omskrywing van die begrip spiritualiteit}

Vir die doeleindes van hierdie artikel is dit nodig om die begrip spiritualiteit in meer besonderhede te omlyn voordat gekom word by die bespreking van die wetenskaplike aktualiteit daarvan. Van der Merwe (2004:425) beskryf spiritualiteit as die oop, eerlike en opregte verhouding waarin 'n gelowige tot God staan. Berg (2002:102) definieer spiritualiteit bondig as die vormgewing van geloof in die daaglikse lewe, dit wil sê om in verhouding met die Here te leef (vgl ook Dreyer 2003:122). An (2001:196) dui spiritualiteit aan as "... essentially the effect in daily life of the unity of our spirit with the Spirit of God, or as Paul described it. 'Keep in step with the Spirit'". Pazmino (1994:143) 
verbesonder spiritualiteit as hy stel dat " $\ldots$ [spirituality] has to do with the manner in which the gospel is both 'lived in' and 'lived out'. Spirituality is first of all living in the gospel - making faith the foundation for life. And it is also living out the gospel - making faith the foundation of action and structure" (vgl ook Treston 1993:96-100). Louw (1997:13-14) beredeneer gereformeerde spiritualiteit vanuit drie hoeke:

- Die teosentriese hoek met as implikasie 'n lewe voor God se aangesig.

- $\quad$ Die geopenbaarde waarheid van die Skrif (vgl ook Pieterse 2005:416417) met as implikasie ' $n$ voortdurende leef uit die Skrif met die konstante eis om te reformeer.

- $\quad$ Die voortdurende wisselwerking tussen Godskennis en selfkennis. Die mens se selfkennis is 'n reaksie op die openbaring (Godskennis).

Vanuit bogenoemde kort uiteensetting word spiritualiteit vir die doeleindes van hierdie artikel soos volg omskryf: Die lewe en dade van die nuwe mens in gemeenskap met God Drie-enig. Die nuwe mens leef primêr vanuit die geopenbaarde waarhede van die Skrif en in gemeenskap met God, maar hy/sy leef ook in gemeenskap met medegelowiges as die volk van God.

\subsection{Die aktualiteit van hierdie ondersoek}

Van der Merwe (2004:385) toon aan dat die postmoderne lewensbeskouing daartoe gelei het dat 'n besondere sterk klem vandag op sake soos spiritualiteit geplaas word. Die strak beklemtoning van rasionele denke pas nie in die sisteem van die postmodernisme in nie (vgl Dreyer 1998:2). Binne die postmodernisme word die klem nie geplaas op een bepaalde godsdiens nie, maar op meer godsdienste, en die mens het hierin 'n vrye keuse ( $\mathrm{vgl}$ Koekemoer 1999:322-333). Daarby moet ook gevoeg word dat die ervaring van jou godsdiens en deel hê aan kerklike besluitneming ook baie klem ontvang (vgl Geyser 1996:6). Uiteraard stel hierdie tendense ook die kerklike kategese voor nuwe verkenningswerk en aksente (bv die uniekheid van Christus en sy werk) wat opnuut beklemtoon moet word. Ook die dimensie van ervaring en verwondering in die kategese behoort na vore te kom ( vgl Beukes 1997:670-690). Aan hierdie aspekte is die spiritualiteit van die katkisant en van die kategeet uiteraard nou verbind (vgl Prins 2004:642-652). 'n Opvallende tendens in huidige navorsing oor spiritualiteit is dat meer aspekte van spiritualiteit betrek word. Venter (1999:187-202) wy aandag aan die Skriffundering van spiritualiteit; so ook Kim en Venter (1998:161-180). Albei hierdie artikels fokus veral op die spiritualiteit van die bedienaar in die prediking. Tidball (1997:120-121) weer konsentreer op die belang van die 
bedienaar se spiritualiteit vir sy herderlike werk. Witvliet (1997:273-298) doen navorsing oor spiritualiteit in soverre dit die liturgiese belewing van die bedienaar en gemeente raak.

Op die vlak van die kerklike kategese is die navorsing oor spiritualiteit en kategeet egter meermale beperk tot paragrawe of enkele bladsye in meer omvangryke werke (vgl bv Van der Merwe 2004:392-397; Dreyer 2003:122; Prins 2000:15-27). Die tema van hierdie artikel moet dus as aktueel beskou word omdat daar leemtes in toepaslike literatuur bestaan oor die aspekte van kategeet en spiritualiteit. Waar die bedienaar die primêre kategeet in die gemeente is, is dit dus nodig dat ook aandag gegee word aan hierdie aspek van 'n predikant se bediening.

Daar is egter nog 'n rede waarom hierdie tema as belangrik beskou kan word. In die proses van kategese vind daar in die klas wisselwerking, identifikasie of modellering plaas tussen kategeet en katkisant. In die Opvoedingswetenskappe word hierdie proses onintensionele leer genoem. Onbewustelik gaan daar dus van die kategeet 'n invloed en werking uit wat 'n sekere nawerking het en 'n stempel afdruk op die katkisant. Hiervoor is die spiritualiteit van die kategeet van kardinale belang, veral aangaande die aard van die stempel wat op die katkisant afgedruk word.

Vanuit bogenoemde motivering sal vervolgens in hierdie onderafdeling op basisteoretiese vlak aandag gewy word aan aspekte van spiritualiteit, veral dan die begrip spiritualiteit, die grond van spiritualiteit en die fundering van die spiritualiteit van die kategeet.

\section{BASISTEORETIESE PERSPEKTIEWE OP KATEGEET EN SPIRITUALITEIT}

In hierdie afdeling word veral gefokus op kategeet en spiritualiteit in die kerklike kategese. Vir die bespreking wat volg, word dit aanvaar dat die primêre kategeet die bedienaar van die Woord is of dat hulpkragte met mindere of meerdere toerusting die bedienaar bystaan.

\subsection{Die voorkoms en betekenis van die begrip spiritualiteit in die Nuwe Testament}

'n Sentrale begrip wat in die Nuwe-Testament gebruik word om spiritualiteit uit te druk is eusebeia. Dié begrip word deur Louw en Nida (1989:532) omskryf as "behavior reflecting correct religious beliefs and attitudes, to live as God would have us live, or to live as God has told us we should live." Balz en Schneider (1991:85) toon aan dat die begrip eusebeia hoofsaaklik in die Pastorale Briewe voorkom (tien keer) en dat die uitdrukking "godvrugtig" lewe, 
eksplisiet gekwalifiseer word as "in Christ Jesus". Dieselfde outeurs beklemtoon in hierdie verband ook dat eusebeiea "has as its goal the fundamental Christological values" (Balz \& Schneider 1991:84-85).

Dit is ook opmerklik dat juis in die Pastorale Briewe - die mees sentrale openbaring oor dienswerk in die Nuwe Testament - die begrip eusebeia meermale direk verbind word met die begrip heiligheid (hagneia). Die begrip heiligheid kom byvoorbeeld voor in 1 Timoteus 4:12 in die sin van opregte en suiwer toewyding (Venter 1999:187-202) en as bewys van die eenheid van die gemeente met Christus. Juis in die Pastorale Briewe word die konsep heilig meermale saam met verbandhoudende begrippe soos lewenswandel, liefde en geloof gebruik om suiwer en opregte toewyding aan God te verwoord.

In verband met die persoonlike toewyding van die bedienaar (i c die kategeet) word die begrip heilig in 2 Timoteus 1:9 gebruik. In hierdie teksvers hou heilig in om uit die sondige wêreld geroep te word om te leef in toewyding in die teenwoordigheid van God en as deel van sy heilige volk.

Die vraag ontstaan dus onwillekeurig aan watter vereistes die lewe van die kategeet in ware spiritualiteit voor God moet beantwoord. In die Pastorale Briewe kom veral vier vereistes na vore (vgl Kim 1997:84, Quinn \& Wacker 2000:37):

- $\quad$ Die eerste vereiste is dat die bedienaar (die primêre kategeet) sal lewe en optree in liefde "uit ' $n$ rein hart, 'n goeie gewete en opregte geloof" (1 Tim 1:5). Die vereiste van liefde word herhaal in 1 Timoteus 1:7.

- $\quad$ Die tweede vereiste vir 'n lewe in ware spiritualiteit is die bereidwilligheid om op te offer en ontberinge te verdra "soos 'n goeie soldaat van Jesus Christus" (2 Tim 2:3-4).

- $\quad$ Die derde vereiste is 'n lewenswandel wat getuig van nederigheid, hier bedoel as die teenoorgestelde van verwaandheid (1 Tim 3:6).

- $\quad$ Die vierde is dat die kategeet heilig moet lewe - afgesonderd van die sonde in die wêreld juis om toegewyd aan God te lewe (1 Tim 5:2).

\subsection{Die begronding van spiritualiteit in die Nuwe Testament}

In die voorafgaande onderafdeling is reeds gestel dat spiritualiteit ' $n$ sterk Christologiese dimensie vertoon en dat ons lewe en lewenswandel in sy geheel beheers word deur ons spiritualiteit. In hierdie onderafdeling word nou dieper ingegaan op die fundering van die spiritualiteit van die kategeet in die werk van Jesus Christus en die konsekwensies daarvan vir die lewe van die kategeet. Die gedeelte wat vervolgens behandel sal word, is Romeine 12:1 en 
2. Die motivering vir dié keuse is dat in hierdie gedeelte direk sprake is van 'n Christologiese dimensie ("ontferminge van God") sowel as van ' $n$ opdrag tot ' $n$ lewe in spiritualiteit in die teenwoordigheid van God ("stel julleself tot beskikking van God"). Die imperatief tot die beoefening van spiritualiteit rus dus in die indikatief van God se ontferming.

Dit is insiggewend om te let op die voorkoms van die begrip ontferming (oiktirmos) juis aan die begin van Romeine 12. Vanuit die breër struktuur van Romeine (vgl Venter 1998:460) is Romeine 12:1-15:13 juis die imperatiewe gedeelte waarin uitvoerig aandag gewy word aan die konsekwensies van die dankofferende lewe in Christus. Die konsep oiktirmos het in Romeine 12:1 die nuanse van "to show mercy and concern with the implication of sensitivity and compassion" (Louw \& Nida 1989:751; Balz \& Schneider 1991:505). Dié begrip behels die betoon van die grootste genade aan iemand wat dit die minste verdien. As sodanig toon die begrip oiktirmos ooreenkoms met die OuTestamentiese begrip chesed, 'n begrip wat gebruik word in verband met God se genadeverbond, en dan spesifiek om aan te dui dat God in verhouding tree met sy volk en teenwoordig is in hulle midde. Snyman (1997:4) toon aan hoe die werklikheid van God se teenwoordigheid in die Ou Testament later vergestalt word in die wolkkolom, die tent van samekoms, die tempel, en in die Nuwe Testament in die Immanuelformule en in die "Ek is"-uitsprake in Johannes.

In Romeine 11 word die begrip eleos omruilbaar met oiktirmos gebruik. Die begrip eleos het weer die nuanse van "to show kindness or concern for someone in serious need" (Louw \& Nida 1989:751). God se ontferming vorm dus die diepste basis waarop die spiritualiteit van die kategeet of Woordbedienaar rus en van waaruit dit prakties uitgeleef behoort te word.

Die grond van ons spiritualiteit roep om die praktyk van spiritualiteit. Hoe lyk die persoonlike geloofslewe van die kategeet/bedienaar dan? 'n Kardinale dimensie van ons spiritualiteit word verwoord in Romeine 12:1(b): "Gee julleself aan God as lewende en heilige offers wat vir Hom aanneemlik is." Die uitdrukking gee julleself aan God kan ook weergegee word met: stel julleself ten dienste van God. Die gedagte is dus dié van volle, algehele oorgawe aan God (vgl Venter 1998:462). Hierdie algehele oorgawe aan God word in hierdie teksvers verbesonder deur die kultiese uitdrukking offer julleself. Hierdie offer moet heilig, lewend en vir God aanneemlik wees. Dit is opvallend dat aan die einde van vers 2 die wil van God ook in drie uitdrukkings beskryf word, naamlik as "goed, aanneemlik en volmaak". Die gerigtheid van die offer op die wil van God is hier opvallend en veelseggend. Spiritualiteit wat voortkom uit die ontferminge van God, moet deur 'n bepaalde lewenswandel gerig word op die wil van God en bepaal word deur die wil van God. 


\subsection{Die Bron van spiritualiteit}

In hierdie verband word verder gefokus op Romeine 12 en wel op vers 2: "Julle moet nie gelykvormig word aan hierdie sondige wêreld nie, maar laat God julle denke vernuwe ...." Vir "sondige wêreld" word die konsep aeon gebruik. Aeon dui hier 'n bedeling aan: die ou bedeling voor die koms van die Messias en die nuwe bedeling na die koms van die Messias. Ons sou ook kon sê die sondebedeling sonder verlossing deur Christus en die verlossingsbedeling ná die koms van Christus. Die krag van die vermaning in vers 2 is dan dat ons opgeroep word om nie die "omlyning" van die ou (sondige) bedeling in ons denke te vertoon nie.

Wat dan wel? "Laat God julle denke vernuwe." Die denke wat vernuwe moet word, is die sondige denke van die ou bedeling. Dit is verhelderend om hierdie oproep tot vernuwing in denke te vergelyk met Efesiërs 4:17-24 waarin ook gehandel word oor die ou en die nuwe lewe. Juis in verse 17 en 18 word gehandel oor 'n bepaalde wyse van denke (die stam nous word telkens gebruik, vgl Venter 2005:1-26):

Vers 17b Die heidene se gedagtes lei tot niks.

Vers 18a Hulle verstand is verduister

Vers 18c Hulle volhard hardnekkig in hulle onkunde.

Hierdie soort denke is identies met die denke van die ou bedeling. Die tipe denke wat geassosieer word met die ou bedeling (gedagtes wat tot niks lei, 'n verstand wat verduister is, onkunde) lei ook tot so 'n tipe lewenswandel (lees: spiritualiteit) wat vereenselwig word met die ou bedeling.

Denke wat vernuut is, word gevind by gelowiges (vgl Muddiman 2001:216) wat volgelinge is van Christus en onderrig is volgens die waarheid wat in Christus is (Ef 4:20). Die opdrag om denke te vernuwe word in Efesiërs weergegee met die woorde "beklee julle met die nuwe mens". Die nuwe mens word gekenmerk deur nuwe denke, 'n nuwe houding, nuwe gedrag en 'n nuwe gesindheid en spiritualiteit (vgl Floor 1995:164; O'Brien 1999:329).

In Romeine 8:2 word die werking van die Heilige Gees direk verbind met die nuwe lewe (denke en lewenswandel) as die Heilige Gees genoem word die "Gees van die lewe in Christus" - die lewe van die nuwe aeon word dus geskep deur die Gees. Ook in Romeine 8:11 word die gee van die nuwe lewe verbind aan die inwoning van die Gees "deur Wie Jesus uit die dood opgewek is". Die Gees wat in ons woon, is dieselfde Gees wat ook die spiritualiteit as vrug van Christus se opstanding in ons skep. Die Gees self is die gawe van die nuwe tyd - die gawe en bron van vernuwende denke en gesindhede en van 'n nuwe (opstandings)spiritualiteit. 


\subsection{Modellering en spiritualiteit}

In die motivering vir hierdie artikel is reeds in die aanduiding van die aktualiteit van die tema gestel dat die kategeet/bedienaar op grond van die aard en diepte van sy spiritualiteit 'n besondere invloed en model kan wees vir katkisante. Juis daarom word ook basisteoretiese gegewens ontgin ten opsigte van modellering - in besonder gegewens in die Nuwe Testament.

Die konsep modellering kom nie in die Nuwe Testament voor nie, maar die begrip voorbeeld word meermale gebruik (vgl Breed 1994:289). Die Griekse begrippe (vgl Meye 1994:201-212) wat in die Nuwe Testament gebruik word om modellering aan te dui is mimeomai (om na te boots), tupos (voorbeeld) en hupodeigma (voorbeeld).

Twee teksgedeeltes word nou nader verken vir die doeleindes van hierdie onderafdeling:

\section{- $\quad 1$ Tessalonisense 1:6}

"En julle het ons voorbeeld gevolg en volgelinge van die Here geword. In baie moeilike omstandighede het julle die woord aangeneem met 'n blydskap wat van die Heilige Gees kom."

Die agtergrond van hierdie woorde van Paulus is dat die brief gerig is aan ' $n$ jong gemeente wat deur hom gestig is. Die nuus wat Timoteus aan Paulus bring, is dat die gemeente standvastig volhard in geloof, liefde en hoop. Hierdie brief skryf Paulus dan om God te dank vir die gemeente en verder om vrae te beantwoord. Wat Paulus in die voorafgaande verse beklemtoon, is dat die woord van God nie net in die prediking met woorde tot hulle gekom het nie, maar ook en veral met krag en deur die Heilige Gees en met volle oortuiging. Afgesien van die werk van die Heilige Gees, dui die begrippe krag en volle oortuiging op die uitwerking van Paulus se spiritualiteit in sy prediking. In Paulus se verkondiging het daar dus ook iets van sy spiritualiteit oorgekom na die gemeente. Hierin is hy dan ' $n$ voorbeeld vir die gemeente. Juis om hierdie rede vervolg Paulus in vers 6: "En julle het ons voorbeeld gevolg en volgelinge van die Here geword" (vgl Van Wyk \& Venter 2003:539).

Paulus en sy medewerkers se praktiese optrede in die gemeente het 'n uitwerking gehad op die bring van die evangelie aan die Tessalonisense. Hulle was self ' $n$ voorbeeld van die krag van die evangelie in hulle eie lewes. Juis om hierdie rede lei hulle die gemeente om soos hulle (Paulus en sy medewerkers) op te tree. Deur Paulus-hulle se voorbeeld na te volg, het die 
gemeente die Here self nagevolg. Dit wat hulle van Paulus ontvang het, het die gemeente hulle eie gemaak en self voortgegaan in ooreenstemming met die riglyne en eise van die evangelie.

\section{- $\quad 1$ Timoteus 4:1}

"Niemand mag op jou neersien omdat jy jonk is nie, maar wees jy vir die gelowiges 'n voorbeeld in woord en gedrag, in liefde, geloof en reinheid."

Die opdrag aan Timoteus om ' $n$ voorbeeld te wees is ingebed in 'n wyer perikoop van vers 6-15 waarin die gedagte van toewyding aan God (spiritualiteit) 'n prominente plek inneem. In vers 7 word Timoteus beveel om hom te oefen om in toewyding aan God te lewe. In die volgende vers ( $(\mathrm{B})$ word die gedagte om in toewyding aan God te lewe herhaal. Vanuit die voorafgaande opdrag tot toewyding volg dan 'n verdere groter gedagte-eenheid waarin gestel word dat die jongman Timoteus vir die gelowiges ' $n$ voorbeeld moet wees in woord en gedrag, in liefde, geloof en reinheid. Die voorbeeld wat Timoteus moet stel, is omvattend. Die opdrag in woord en in daad hou in dat hy 'n voorbeeld moet stel in wat hy sê en in hoe hy hom gedra. Hierin moet hy ' $n$ voorbeeld wees van ' $n$ Christelike gesindheid wat agter die dade lê. Liefde is "the pre-eminent Christian grace to be shown to the neighbour and to all humankind" (Stott 1997:120). Geloof het hier betrekking op vertroue in God, maar ook op Timoteus se eie betroubaarheid. Reinheid het veral betrekking op selfbeheersing ( $\mathrm{vgl}$ Johnston 2001:252). So moes Timoteus in sy spiritualiteit 'n omvattende voorbeeld stel. "People would not despise his youth if they could admire his example" (Stott 1997:120).

\subsection{Samevatting van basisteoretiese bevindings}

- Die spiritualiteit van die kategeet het tot inhoud die gesindheid, lewe en dade van die nuwe mens wat leef in gemeenskap met God Drie-enig. Hierdie gemeenskap met God fokus op Christus se versoeningswerk, geskied vanuit die geopenbaarde waarheid van die Skrif, word voltrek in gemeenskap met medegelowiges en is gerig op alle mense.

- $\quad$ Die spiritualiteit van die kategeet hou in dat hy teenoor katkisante optree in liefde, met 'n opregte hart, in geloof, met 'n goeie gewete en in heiligheid. 
- $\quad$ 'n Lewe in spiritualiteit hou in dat die kategeet bereid moet wees om ontberinge vir Christus te dra.

- $\quad$ Nederigheid (in teenstelling met verwaandheid) moet 'n kenmerk wees van die spiritualiteit van die kategeet.

- $\quad$ Die ontferminge van God is die diepste grond waarin die spiritualiteit van kategeet en katkisante gefundeer moet word.

- $\quad$ Spiritualiteit vind prakties gestalte in oorgawe aan God as lewende dankoffer.

- $\quad$ In die denke, lewe en dade van kategeet en katkisant funksioneer die Heilige Gees as die Bron en Bewerker van 'n nuwe spiritualiteit in ' $n$ nuwe aeon.

- $\quad$ Modellering van katkisante met kategeet vind plaas waar die oordrag van die evangelie nie net met woorde nie, maar ook met dade en in 'n gesindheid van oorgawe aan Christus plaasvind.

- Die spiritualiteit van die kategeet in die oordrag van die Woord moet die kenmerke van liefde, geloof en selfbeheersing vertoon.

- Katkisante wat die geloofsvoorbeeld van die kategeet sien en volg, is in wese nie volgelinge van die kategeet self nie, maar navolgers van die Here.

- $\quad$ Die spiritualiteit van kategeet en katkisante moet geoefen word onder andere langs die weg van kerklike kategese.

\section{METATEORETIESE PERSPEKTIEWE OP KATEGEET EN SPIRITUALITEIT}

In 'n nadere omskrywing van wat in hierdie artikel onder spiritualiteit verstaan word, is reeds bondig gestel dat dit die lewe en dade of praktyke van die nuwe mens in Christus omvat. Hierdie nuwe lewe kom dus ook in 'n bepaalde gesindheid en optrede na vore teenoor die naaste en alle mense - en dus ook in die praktyk van sy of haar roepingsvervulling as kategeet teenoor katkisante. Spiritualiteit raak dus die kategeet as mens in sy totaliteit.

Op metateoretiese vlak sal in hierdie afdeling aan die volgende sake aandag gewy word: kategeet, spiritualiteit en persoonlikheid, emosionele intelligensie, kundigheid, identifikasie en praktiese onderrig in 'n leersituasie.

\subsection{Kategeet, spiritualiteit en persoonlikheid}

Dit lê nie op die weg van hierdie artikel om breed in te gaan op definisies, gedrag, taksonomie en ander aspekte rondom persoonlikheid nie. 'n Nadere 
omskrywing van wat onder persoonlikheid verstaan word, is egter toepaslik. Kruger (2002: 82) behandel bepaalde probleme rondom die definiëring van persoonlikheid. Hierdie probleme hou verband met die aksente van verskillende skole in die Psigologie oor persoonlikheid, byvoorbeeld die nomotetiese en idiografiese rigtings van persoonlikheidsnavorsing. By die volgende definisie van Kruger (2004:21) word aangesluit vir die onderwerp van hierdie artikel: Persoonlikheid het te doen met die vaste denk- of gedragspatrone wat min of meer deurlopend by ' $\mathrm{n}$ persoon voorkom, wat aan hom 'n eie, unieke en uitkenbare identiteit gee" (vgl ook Hyde 1991:146-151; Venter 2004:440).

Wat vir hierdie artikel van belang is, is dat in resente ondersoek Kruger (2002:116) tot ' $n$ indeling van persoonlikheidstipes kom volgens die oktale sirkumpleks. Hiervolgens kan gepraat word van die volgende persoonlikheidstipes: 'n outokraties besturende, 'n kompeterend uitbuitende, 'n aggressief reguit, ' $n$ skepties wantrouige, ' $n$ nederig selfnihilerende, 'n goedgeaard afhanklike, 'n saamwerkend oorkonvensionele, en 'n verantwoordelik hipernormale persoonlikheidstipe. 'n Meer resente ontwikkeling is die ontstaan en gebruik van die sogenaamde Vyfmodelfaktor wat die volgende verdere dimensies van persoonlikheid bied (Kruger 2002:148):

- ekstroversie (warmte, gulhartigheid, matige selfgelding);

- inskiklikheid (vertroue, opregtheid, altruïsme);

- konsensieusheid of gedragsbeheerstheid (vaardigheid, pligsbesef, orde);

- neurotisisme (angs, woede, vyandigheid, depressie);

- openheid vir ervarings (kultuur, godsdiens, intellek, verbeelding, estetika).

Uit die uiteensetting hierbo is die volgende van belang in verband met die kategeet, sy spiritualiteit en sy persoonlikheid: Die kategeet se spiritualiteit sal die beste na vore kom, invloed uitoefen en 'n voorbeeld stel aan katkisante as hy ' $n$ nederige, maar nie ' $n$ algeheel selfnihilerende persoonlikheid het nie. Ook iemand met 'n goedgeaarde, maar nie te afhanklike persoonlikheid nie, iemand wat die gawes van vertroue, gulhartigheid en na-buitegerigtheid het, se spiritualiteit sal 'n positiewe invloed uitoefen op katkisante. 'n Meewerkende, maar nie oorkonvensionele persoonlikheid nie, kan ' $n$ deur oopmaak na vaardigheid, pligsbesef en orde en ook na openheid vir nuwe ervarings in die gang van die kategetiese onderrig (vgl ook Treston 1993:99).

Gesien vanuit die omvattende omskrywing van die spiritualiteit van die kategeet/bedienaar vir die doeleindes van hierdie artikel, naamlik dat dit nie 
net gaan oor spiritualiteit as teorie nie, maar ook om die praktykwording in die kategese, kom 'n dimensie wat verband hou met die persoonlikheid van die kategeet na vore. Vanuit sy eie beoefening van spiritualiteit behoort die kategeet ook rekening te hou met die psigologiese ontwikkeling van die kind tydens bepaalde leeftydsfases en die toespitsing daarop in die kategese (vgl Clark 1994:235; Lee 1985:17-19). Van die mees toepaslike navorsing hieroor is dié van Richards en Bredfeldt (1998:100-107). Hulle stel dat die emosionele ontwikkeling tydens die voorskoolse fase veral die volgende aspekte omvat: die kind voel onseker in nuwe situasies en tussen vreemdelinge en hy of sy leer deur ontdekking. Hierby kom dat 'n bepaalde roetine en herhaling van leerstof nodig is en ook dat in gedagte gehou moet word dat die jong kind 'n egosentriese lewensingesteldheid het en nog nie 'n ander persoon se perspektief kan insien nie. Hierdie waarneming hou in dat werk aan die kind verduidelik moet word vanuit sy of haar beperkte insig. Daarvoor is dit weer nodig dat dieselfde onderrigpatroon in elke klas gevolg moet word. In die klas moet 'n atmosfeer van geborgenheid en veiligheid geskep word.

Tydens die sogenaamde laerskoolfase is die oorheersende emosionele trekke van kinders dat hulle besonder gevoelig is en dus maklik seerkry. Daar is by hulle ' $n$ begeerte en behoefte om aanvaar te word (ook in 'n groep). Vanuit sy spiritualiteit moet die kategeet met hierdie groep veral met empatie en aanmoediging werk en positiewe groepsbetrokkenheid moet aangemoedig word.

In die vroeë adolessente tydperk word veral gesoek na 'n eie identiteit, na groter selfstandigheid en fluktueer emosies dikwels. Hierdie belewing bied aan die kategeet die geleentheid om in sy onderrig te fokus op ons identiteit in Christus, om aan die katkisant groter vryheid en selfstandigheid te bied en veral om vanuit sy eie spiritualiteit geduld en verdraagsaamheid teenoor die katkisant te beoefen.

\subsection{Kategeet, spiritualiteit en emosionele intelligensie}

Onder die term emosionele intelligensie word vir die doeleindes van hierdie artikel die volgende verstaan: die vermoë om eie en ander se gevoelens te verstaan, om eie gevoelens te kan uitspreek en om selfgemotiveerd te kan werk (vgl Goleman 1998:317; Venter 2005:12). Uiteraard sou meer definisies van emosionele intelligensie gebied kon word. Wat egter telkens na vore kom in omskrywings van emosionele intelligensie is die voorkoms van woorde soos: gevoelens, selfbewussyn, "ability", "capacity, en "competence" om eie en ander se gevoelens raak te sien, te interpreteer en te hanteer (Venter 2005:13). 
Covey (2004:344-345) bevind in sy navorsing dat emosionele intelligensie hoofsaaklik uit die volgende vyf komponente bestaan:

- $\quad$ Selfbewussyn: Hieronder word verstaan die vermoë om insig te toon in jou eie lewe, om te groei in selfinsig en om eie swakhede te oorkom of minstens daarvoor te kompenseer (vgl ook Hands \& Fehr 1993:59).

- $\quad$ Persoonlike gemotiveerdheid: Hierdie komponent hou onder andere in om te werk vanuit 'n bepaalde visie, doelwitte en met vasberadenheid en passie.

- $\quad$ Selfbestuur: Hieronder word verstaan die vermoë om jou lewe te bestuur vanuit sekere waardes.

- $\quad$ Empatie: Empatie hou in om in staat te wees om te sien hoe ander sien en te voel hoe ander voel. Dit beteken om eers ander te wil verstaan en nie om eers self verstaan te wil word nie (vgl Miller 1985:69).

- $\quad$ Sosiale vaardighede: Hierdie vaardigheid omvat die vermoë om verskille en konflik te kan hanteer en om probleme te kan oplos.

Gesien vanuit die perspektief van sy/haar eie spiritualiteit en in sy/haar praktiese optrede in en buite die katkisasieklas, is dit vir die kategeet ook nodig om insig te toon in katkisante se emosies. Die rede hiervoor is dat emosies nie net aangenaam of onaangenaam kan wees nie, maar ook motiveerders van gedrag kan wees. Verder is dit so dat daar 'n noue verbinding is tussen emosies en denke (gedagte). Gedagtes dien as 'n sneller vir die aktivering van emosies (vgl Vermeulen 1999:43). Emosies kan weer in vier hoofgroeperinge verdeel word, naamlik vrees, woede, droefheid en gelukkigheid (Venter 2005:17-18).

Wat in besonder in gedagte gehou moet word, is dat kennis en die toepassing van emosionele intelligensie 'n wesenlike bydrae kan lewer in die identifikasieproses van die katkisant met die kategeet.

\subsection{Kategeet, spiritualiteit en die identifikasieproses}

Dit is reeds by herhaling beklemtoon dat die spiritualiteit van die kategeet verband hou met hoe hy of sy die evangelie na binne beleef en na buite uitleef. Die spiritualiteit van die kategeet na buite kom op min plekke so pertinent na vore as in die aspek van die kategeet as identifikasiefiguur, of as iemand met wie 'n katkisant kan modelleer of sosialiseer (vgl De Wet 2003:1461-1485). 
Richards (1980:83) omskryf die proses van identifikasie as “... a process in which a person believes himself to be like another person in some respects, experiences the other's successes and defeats as his own, and consciously models his behavior after him .... The fact that there is emotional involvement with the other person distinguishes identification from mere imitation." Dit is juis op die terrein van identifikasie waarvan, volgens die navorsing van Prins (2005:495), daar nog baie min in die praktyk van die kerklike kategese tot sy reg kom.

Die konkrete uitleef van sy of haar spiritualiteit in die kerklike en lewenspraktyk, omvat juis ook die voorwaardes wat geld vir die identifikasie van die katkisant met die kategeet. Richards (1980:84-85) omlyn die volgende gunstige faktore wat identifikasie in kategese bevorder:

- Daar moet oor 'n lang termyn blootstelling wees tussen kategeet en katkisant.

- $\quad$ Daar moet 'n innige, opregte vertrouensverhouding wees met die persoon met wie geïdentifiseer word.

- $\quad$ Die katkisant moet ook iets van die innerlike lewe van die kategeet kan ervaar (byvoorbeeld hoe hy/sy self die genade van Christus ervaar en uitleef in 'n tyd van swaarkry).

- $\quad$ Vir identifisering moet blootstelling in 'n verskeidenheid lewensituasies plaasvind (vgl ook Pretorius 2005:129-139).

- $\quad$ Die kategeet moet standvastig wees in beginsels en optrede (gedrag) anders word identifikasie belemmer.

- $\quad$ Indien die leer en lewe van die kategeet nie kongruent met mekaar is nie, word identifikasie onmoontlik of baie moeilik. "Be aware of the behaviors and attitudes you model as a teacher" (Richards \& Bredfeldt 1998:274).

- $\quad$ 'n Nadere toeligting van gedeelde geloofservaringe tussen kategeet en katkisant bevorder identifikasie.

Alles wat hierbo gestel is, beklemtoon die plek van vertroue in die identifikasieproses (vgl Dingemans 1991:123-124). In hierdie verband kan genoem word dat daar in toepaslike vakliteratuur sprake is van twee soorte sosialisering. Sosialisering kan deur intensionele leer plaasvind. Intensionele leer vind doelbewus plaas deur middel van onderrig en beïnvloeding om 'n sekere doel te bereik. Hiervan is kerklike kategese 'n goeie voorbeeld (vgl 


\section{Kategeet en spiritualiteit}

Dreyer 2003:89). Onintensionele sosialisering hou in dat 'n katkisant in die sosialiseringsproses leer deur waarneming en 'n bepaalde vaardigheid of gesindheid aanleer, sonder dat die intensie van onderrig teenwoordig was (Van Wyk \& Venter 2003:8; vgl Pretorius 2005:129-139).). Onintensionele identifikasie vereis by die kategeet eienskappe soos toeganklikheid, die vermoë om kreatief te luister, geduld, egtheid in sy omgee vir die katkisant en opregtheid om te help. Die grootste vereiste is egter toewyding aan Christus in die konkrete beoefening van die kategeet se spiritualiteit.

\subsection{Kategeet, spiritualiteit en leermetodes}

Wat die kategeet in gedagte moet bly hou om te dien as identifikasiefiguur is die wyse waarop kinders leer. Kinders leer optimaal indien hulle self betrokke is in die ontdekking van die waarheid (vgl Cho \& Prins 2005:78-86). Hierdie leermetode hou in dat daar byvoorbeeld 'n oop klasatmosfeer behoort te wees en die moontlikheid om met vrymoedigheid vrae te vra. "Youth must come to the point where they own faith themselves. This only happens when questions can be comfortably asked without any fear of negative reactions" (Richards \& Bredfeldt 1998:262). 'n Volgende aspek is dat katkisante makliker identifiseer indien die lesse toepaslik aangebied word en gerig word op bepaalde behoeftes van die katkisant. Daarby moet in gedagte gehou word dat onderrig wat identifikasie dien, 'n dimensie van ervaring behoort in te hou. Die leerproses moet ook die komponent van ervaring inhou en nie net 'n mondelinge aanbieding wees wat alleenlik gerig is op kennisoordrag nie. Die proses van herhaling met variasie (byvoorbeeld in die konsentriese metode) kan 'n sinvolle doel dien. Miskien is die belangrikste leermetode dat kinders leer en identifiseer met die kategeet indien 'n les konkreet aangebied en ervaar word, omdat veral jonger kinders letterlik en konkreet dink.

\subsection{Samevatting van metateoretiese bevindinge}

- $\quad$ As ideaalbeeld van die persoonlikheid van 'n kategeet/bedienaar geld die dimensies van ekstroversie, inskiklikheid, vaardigheid en openheid - nie net vir die rasionele nie, maar ook vir die ervaringsmatige.

- $\quad$ Omdat die kategeet se eie spiritualiteit ook in die praktyk van die kategese na vore kom, behoort hy rekening te hou met die emosionele ontwikkeling van katkisante in die verskillende leeftydsfases. In die aanbiedingwyse, inkleding en toepassing van die kategese behoort hy hom ook toe te spits op die emsionele behoeftes van katkisante.

- $\quad$ Emosionele intelligensie hou in dat die kategeet vanuit sy spiritualiteit insig toon in sy eie lewe en gevoelens en dat hy/sy in staat sal wees 
om ook gevoelens in die lewe van katkisante te herken en sodanige gevoelens te interpreteer, byvoorbeeld in die geval van konflikhantering. Hierby moet hy of sy persoonlik gemotiveerd werk en vanuit 'n eie visie en doelwitte sy/haar eie lewe bestuur.

- $\quad$ Aspekte wat die positiewe identifikasie van die katkisant met die kategeet dien en bevorder, hou in dat daar oor 'n lang termyn blootstelling tussen kategeet en katkisant moet wees in 'n opregte, oop en vertrouensvolle verhouding waarin die katkisant ook iets van die innerlike belewing en uitlewing van die spiritualiteit van die kategeet waarneem. Gedeelde geloofservaringe tussen kategeet en katkisant bevorder identifikasie.

- Indien die leer en lewe van die kategeet inkongruent met mekaar is, maak dit identifikasie tussen katkisant en kategeet bykans onmoontlik.

- Identifikasie word ook bevorder deur ' $n$ helder, duidelike en konkrete aanbiedingswyse in die katkisasie met 'n toespitsing ook op die behoeftes en leeftydfase van die katkisante.

\section{PRAKTYKTEORETIESE PERSPEKTIEWE}

\subsection{Kategese impliseer nie die blote oordrag van kennis nie}

Miskien is die belangrikste enkele bevinding van hierdie ondersoek dat kategese nie opgaan in die blote oordrag van kennis nie en dat hierdie kennis ook nie meganies oorgedra behoort te word nie. Die doel van die kategese is nie om teoloë te kweek nie, maar mense wat hulle geloof bely. Kennis van God moet lei tot die ken van God, dit wil sê om in 'n persoonlike verhouding tot God te staan. Die mens in sy geheel word betrek in die ontvang van kategetiese onderrig. Die oordrag in die kategetiese onderrig bemiddel as 't ware dat God in sy Woord tot die katkisant kom. In die kategetiese proses word die kategeet ook as mens in sy geheel betrek - met al sy gawes, persoonlikheid en bowenal met sy geloof en die praktiese uitlewing van sy geloof en toewyding aan die Here.

\section{2 'n Kategeet moet die band met God persoonlik beleef}

Vanuit hierdie sentrale bevinding kan dit as noodsaaklik beskou word dat aspekte van die spiritualiteit van die kategeet deur 'n kerkraad in ag geneem moet word wanneer hulpkragte gevra om om die predikant by te staan met die kategetiese onderrig. Voorop staan die vereiste dat sodanige hulpkragte innige gelowiges moet wees wat die band met God persoonlik beleef en 
deurleef. Niemand kan slaag as kategeet maar druip as gelowige nie. So 'n situasie blokkeer identifikasie tussen katkisant en kategeet. Hierby is dit ook nodig dat gelet word op aspekte wat in hierdie artikel op metateoretiese vlak na vore gekom het. Dit sluit sake in soos die aard en funksionering van die persoonlikheid van die kategeet. Beskik hy of sy oor 'n warm, uitgaande en empatiese persoonlikheid? Hoe funksioneer die verskillende aspekte van sy of haar emosionele intelligensie? Is daar voldoende selfbeheersing, ' $n$ helder selfbewussyn, insig in sy/haar eie gevoelens en in dié van ander? Op watter vlak funksioneer sy/haar selfbestuur en sosiale vaardighede? Leen die persoon hom- of haarself tot identifikasie deur die katkisante?

\subsection{Praktiese beoefening van spiritualiteit is noodsaaklik}

Nie net die noodsaak om vas te stel of die nodige spiritualiteit by ' $n$ kategeet of hulpkategeet aanwesig is, is belangrik nie, maar ook die verdere toerusting in die praktiese oefening van spiritualiteit na binne en die praktiese beoefening na buite behoort aandag te ontvang. Dit sou inderdaad 'n blye dag wees indien op die gereelde kategetevergaderings nie alleen klasbywoning en katkisante se voorbereiding van werk regmatige aandag ontvang nie, maar ook die oefening en uitlewing van die kategeet se spiritualiteit, byvoorbeeld in die praktiese kategese. Sou dit nie sinvol wees indien veertig minute van so 'n kategetevergadering afgestaan word aan toepaslike Bybelstudie, bepeinsing en gebed spesifiek oor die eie spiritualiteit nie? Sou daar nie beplan kan word hoe ' $n$ kategeet op ' $n$ toepaslike geleentheid in die klas sy eie geloofservaring in 'n bepaalde situasie kortliks op 'n empatiese - en nie sentimentele wyse nie - met die katkisante kan deel nie? Sou nie ook beplan kan word om aan katkisante ' $n$ geleentheid te bied om die praktiese uitwerking van hulle geloof in ' $n$ bepaalde situasie in die afgelope week te deel met die klas nie?

\subsection{Spirituele oefening om fiks te bly}

Die bewuste oefen van jou spiritualiteit en die belewing van jou eie geloof is vir enige gelowige nodig. Vir die predikant as toeruster van katkisante is dit des te meer nodig om hom/haar daadwerklik te beywer om sy/haargeloof spierkragtig en fiks te hou. As kategeet moet hy/sy immers help vorm aan die lewens, die gemoed en die insig van kinders wat in die kategeseklas teenwoordig is. Juis daarom moet ' $n$ kategeet voortdurend bid dat die Heilige Gees self sy woorde sal rig, sy dade sal motiveer en die oordragproses in die onderrig van katkisante sal bemiddel. 


\section{Literatuurverwysings}

An, J S 2001. Creative Bible teaching to young children. PhD dissertation, Potchefstroom University for CHE.

Bergh, S J 2002. Gesinsbediening as 'n geïntegreerde deel van die opbou van die gemeente. PhD-proefskrif, Universiteit van die Vrystaat.

Balz, H \& Schneider, G 1991. Exegetical dictionary of the New Testament, vol 2. Grand Rapids, MI: Eerdmans.

Beukes, M J du P 1997. Kerkleiding in die een en twintigste eeu. HTS 53, 670-690.

Breed, G 1994. Kategese as geloofsopvoeding. ThD-proefskrif, Potchefstroomse Universiteit vir $\mathrm{CHO}$.

Cho, H J \& Prins, J M G 2005. The use of storytelling in the practice of Christian education. NGTT 46, 78-86.

Clark, R 1994. Spiritual formation in children, in Gangel, K K \& Wilhoit, J C (eds), The Christian educator's handbook on spiritual formation, 234-246. Wheaton: Victor.

Covey, S R 2004. The $8^{\text {th }}$ habit: From effectiveness to greatness. London: Simon \& Schuster.

De Wet, D C 2003. 'n Gemeenskapsgerigte model vir die geloofsvorming van tieners deur middel van simbole en rituele. HTS 59, 1461-1485.

Dingemans, G D J 1991. In de leerschool van het geloof: Mathetiek en vakdidaktiek voor catechese en kerkelijk vormingswerk. Kampen: Kok.

Dreyer, T F 2003. Die rol van die gemeente as 'n gemeenskap van gelowiges in begeleiding tot belydenisaflegging. MTh-skripsie, Potchefstroomse Universiteit vir $\mathrm{CHO}$.

Dreyer, T F J 1998. Teologiese opleiding en spiritualiteit, Die Hervormer 19(1), 5.

Floor, L 1995. Efeziers: Een in Christus. Kampen: Kok.

Geyser, P 1996. Predikantwees en spiritualiteit, Die Hervormer 89(16), 6.

Goleman, D 1998. Working with emotional intelligence. London: Bloomsbury.

Hands, D R \& Fehr, W L 1993. Spiritual wholeness for clergy: A new psychology of intimacy with God, self and others. New York: Alban.

Hyde, K E 1991. Adolescents and religion, in Ratcliff, D \& Davies, J A (eds), Handbook of youth ministry, 119-161. Alabama, AL: Religious Education Press.

Johnston, G 2001. Preaching to a postmodern world: A guide to reaching twenty-first century listeners. Grand Rapids, Ml: Baker.

Kim, H K 1997. Preacher and spirituality: A diaconiological study in the light of the Pastoral Epistles. MA dissertation, Potchefstroom University for CHE.

Kim, H K \& Venter, C J H 1998. Preacher and spirituality: Perspectives from the Pastoral Epistles. In die Skriflig 32, 127-144.

Koekemoer, J H 1999. Die Heilige Gees en spiritualiteit in teologiese opleiding. HTS $55,322-333$.

Kruger, S F 2000. Menslike persoonlikheid en toerustende herderlike bediening. Aspekte van 'n metateorie, basisteorie en praktykteorie. ThD-proefskrif, Potchefstroomse Universiteit vir $\mathrm{CHO}$.

Kruger, S F 2004. Verandering in die kerk: Maak seker jy verstaan dit. Middelburg: Outeur. 
Lee, J M 1985. Lifework spirituality and the religious educator, in Lee, L M (ed), The spirituality of the religious educator, 7-42. Alabama, AL: Religious Education.

Louw, J P \& Nida, E A 1989. Greek-English lexicon of the New Tetament based on semantic domains, vol 1. Cape Town: United Bible Societies.

Louw, D J 1997. 'n Diagnostiese model vir die assessering van spiritualiteit met die oog op geloofsontwikkeling in die pastorale bediening. Praktiese Teologie in Suid-Afrika 12(2),11-25.

Meye, R P 1994. The imitation of Christ: Means and end of spiritual education, in Gangel, K O \& Wilhoit, J C (eds), The Christian educator's handbook on spiritual formation, 199-212. Wheaton: Victor Books.

Miller, R C 1985. Process spirituality and the religious educator, in Lee, L M (ed), The spirituality of the religious educator, 66-87. Alabama, AL: Religious Education.

Muddiman, J 2001. A commentary on the epistle to the Ephesians. London: Continuum.

O'Brien, P T 1999. The letter to the Ephesians. Leicester: Apollos.

Pazmino, R W 1994. Nurturing the spiritual lives of teachers, in Gangel, K O \& Wilhoit, J C (eds), The Christian educator's handbook on spiritual formation, 143-153. Wheaton: Victor Books.

Pieterse, H J C 2005. Die rol van Godskennis in die ontmoetingsgebeure met God in die prediking. In die Skriflig 39, 409-422.

Pretorius, W A 2005. Wat doen ons aan ons kinders? Wie dra wat oor na die volgende geslag? Praktiese Teologie in Suid-Afrika 20(2), 129-139.

Prins, J M G 2000. Geloofsoortuigings, -ervarings en -gedrag van kerklik betrokke tieners - verslag van 'n empiriese ondersoek. NGTT 41, 5-27.

Prins, J M G 2004. Die doelstellings en evaluering van kerklike jeugprogramme - met spesifieke verwysing na die praktyk in die NG Kerk. NGTT 45, 642-652.

Prins, J M G 2005. Programinhoude van die kinder- en jeugbediening van die NG kerk (II): Die fokus op die gesin en die persoonlike geloofslewe. NGTT 46, 486-498.

Quinn, J D \& Wacker, W C 2000. The first and second letters to Timothy. Grand Rapids, MI: Eerdmans.

Richards, L O 1980. A theology of Christian education. Grand Rapids, MI: Zondervan.

Richards, L O \& Bredfeldt, G J 1998. Creative Bible teaching. Chicago, IL: Moody.

Snyman, S D 1997. Spiritualiteit: 'n Perspektief uit die Ou Testament. In die Skriflig 31,1-13.

Stott, J R W 1997. The message of Timothy and Titus. Leicester: Inter-Varsity Press.

Treston, K 1993. A new vision of religious education. Mystic: Twenty-Third Publications.

Tidball, D 1997. Skilful shepherds: Explorations in Pastoral Theology. Leicester: Apollos.

Van der Merwe, C N 2004. Kategese as middel tot heilsekerheid en heils-toe-eiening in konteks van die verbond en die koninkryk. PhD-proefskrif, NoordwesUniversiteit, Potchefstroomkampus.

Van Wyk, G \& Venter, C J H 2003. Die gelowige ouer as geloofsvoorbeeld. Praktiesteologiese perspektiewe op toerusting. In die Skriflig 37, 533-554.

Venter, C J H 1998. Spiritualiteit in die lig van Romeine 12. In die Skriflig 32, 457468. 
Venter, C J H 1999. Die spiritualiteit van die prediker met verwysing na sy toerustingstaak. In die Skriflig 33, 187-202.

Venter, C J H 2004. Die predikant wat houe uitdeel: Die gemeente as teiken. In die Skriflig 38, 429-449.

Venter, $\mathrm{C} \mathrm{J} \mathrm{H} \mathrm{2005.} \mathrm{Aspekte} \mathrm{van} \mathrm{emosionele} \mathrm{intelligensie} \mathrm{in} \mathrm{die} \mathrm{lewe} \mathrm{van} \mathrm{die} \mathrm{nuwe}$ mens. In die Skriflig 39,1-26.

Vermeulen, S 1999. EQ emotional intelligence for everyone. Rivonia: Zebra.

Witvliet, J D 1997. The spirituality of the Psalter: Metrical Psalms in liturgy and life in Calvin's Geneva. Calvin Theological Journal 32, 273-297. 